\title{
Sulla and the practices of anchoring in political discourse: cultural memory and the use of symbols in Roman Athens
}

\author{
Manolis E. Pagkalos \\ (University of Groningen)
}

\begin{abstract}
This paper discusses strategies of negotiating Roman control over Athens in a contested political sphere during the first century BCE. It explores the language in Athenian political discourse, political reactions to Roman power, and the ideological grounds for decision-making in the pre- and post-Sulla periods, tracing continuity in practices and focusing on the iconographical choices of the New Style coinage of Mentor and Moschion. To that end, it examines the different articulations of power as manifested at a symbolic level; it traces reforms in Athenian civic narratives in a period of increasing Roman activity in the East; it highlights links between Athenian cultural memory and decision-making during this period; finally, it explains the ways the embedded, new narratives were disseminated. The evidence shows significant political fluidity in first-century Athens and mirrors the political elites' understanding of the role of the past and the need for constructing new political narratives depending on circumstances.
\end{abstract}

\section{Keywords}

Roman Athens; Sulla; siege of Athens; coinage; political discourse; memory; anchoring innovation

\footnotetext{
The research for this article was funded by Anchoring Innovation, which is the Gravitation Grant research agenda of OIKOS, the National Research School in Classical Studies, the Netherlands. It is financially supported by the Dutch ministry of Education, Culture and Science (2017-2027). For more information see www.ru.nl/oikos/anchoring-innovation. An early version of this research paper was presented at the Laetae Segetes VII Conference (Brno, 18-20 November 2020). I am extending my gratitude to Prof. Onno van Nijf, Dr Stefanos Apostolou, the two anonymous reviewers, and my colleagues from the Department of Ancient History at Groningen for the insightful comments and thought-provoking discussions at various stages of this work. All remaining mistakes are, of course, mine. All translations provided are my own unless otherwise indicated. If not indicated, dates should be taken as BCE.
} 


\section{Introduction}

On 1 March 86, Lucius Cornelius Sulla entered Athens as a conqueror, having besieged Athens since the previous autumn. ${ }^{1}$ In the long Hellenistic period, it was an unprecedented event for the Athenians, who had tried to regain their status and autonomy numerous times against their Macedonian overseers. Indeed, this was the first time the city was besieged and partially destroyed since the Persian Wars. ${ }^{2}$ Arguably, this was a shock to the Athenians and a turning point in the history of the polis, which felt for the first time the brute power of the Romans.

First, I argue that, notwithstanding the reception of the siege in later sources and the creation of a literary topos with seemingly exaggerated narratives (Kuin 2018), ${ }^{3}$ the siege and the partial destruction of the polis were not an eventuality or a threat but a reality. Unlike the events after the Battle of Chaironeia (338), for example, when the Athenians panicked at the possibility of Philippos II's attack, the siege by Sulla and its horrors created a reality similar in magnitude and perception to the destruction of the city during the Persian Wars. In the aftermath of the siege and the capture of Athens by Sulla, the Athenians should have felt as humiliated as they might have when they were forced to demolish their Long Walls at the end of the Peloponnesian War (404). The destroyed buildings, many of which were only much later repaired, ${ }^{4}$ would have been a constant reminder of the changing fates of the polis, thus acting as 'sites of memory'.

Then, this paper focuses on how the Athenians negotiated with Sulla and the Romans in the wake of their defeat. It is a preliminary inquiry at the level of incorporating ambient developments, notably the violent seizing of the polis by Sulla, into civic narratives based on their suitability in establishing a shared space, an area of political discourse. This common ground does not need to be (and if fact it is not) only verbal. Symbolism often plays an essential role and could have worked, in this case, towards (re)building the relationship between the Athenians and the Romans via serving both Athenian and Roman objectives.

Moreover, the paper investigates how and to what extent the Athenian society accepted the harsh realities imposed by Sulla by effectively integrating them into long-standing civic conceptual categories and values. Under this perspective, I also discuss the existence of complex narrative(s) within Athenian political discourse that can embed, with different depth, changes according to civic needs. In other words, I am looking at the

1 Plut. Sull. 12-14; App. Mith. 30-41.

2 Two instances of destruction during the Persian Wars, in 480 and 479, Hdt. 8.53; 9.13. This excludes the razing of the cemetery for building material to strengthen the city walls after the Battle of Chaironeia (338) in anticipation of Philippos' advance, Dem. 18.248; Aesch. 3.236; Lycurg. 1.44; cf. Conwell (2008: pp. 133-159).

3 Cf. Eckert (2016: pp. 86-102).

4 Most of the buildings were repaired, with some probability, in the second century CE; see Hoff (1997); Parigi (2019).

5 For the destruction in Athens see Hoff (1997: pp. 40-41); Ruggeri (2006); Mango (2010: pp. 117-125); Eckert (2016: pp. 95-97); Parigi (2019). 
very instruments of anchoring that the Athenians utilised to highlight their competence and long tradition. Anchoring practices are common in different societies, groups, and periods (Sluiter 2017), and the Athenians are not an exception; they have had, as I argue, much experience (not unlike other ancient and modern societies) in finding some value in contemporary realities, selecting some aspects, and integrating them into familiar narratives, building upon their cultural memory.

The very concept of anchoring innovations is, of course, central in creating the common language (in a broad sense) employed for the negotiation of power and the construction of new, familiar narratives that can work with different audiences. At the same time, symbolism is also inextricably linked to political discourse. ${ }^{6}$ It often frames the language of negotiation (and, in turn, is framed by it), and it can take various forms. From linguistic aspects and the use of vocabulary to ideological constructs, symbols can be abstract and remain as ambiguous and open to interpretation as words can sometimes be. Thus, this paper explores the notion of this 'language' by looking at symbolisms rather than actual language and opens the door for complementary research on other elements of this 'discourse', of the dynamic processes of meaning and interpretation that always imply intentionality and contextual connections.

The paper begins with a discussion of Athenian practices of anchoring innovations in the Hellenistic period that paved the ground for the developments in first-century BCE Athens. The aim is to illustrate the prevailing civic narrative built upon the long-standing cultural memory of the Athenians. Then, I move to symbolism and examine the so-called Athenian New Style coinage minted during the Mithridatic Wars to trace how narratives changed and to detect the agency behind these changes. Finally, epigraphy offers some support as an afterword to this paper and a precursor of further research on the multifaceted manifestation of 'language' in Roman Athens' narratives.

\section{Athenian Practices of Anchoring: A View from the Second Century}

To discuss what may have happened in early Roman Athens at the time of the Sullan affair, it is beneficial, I believe, to look further back in the past of the polis and explore continuation. The previous two centuries provide context and reveal long-term practices and conventions.

From an external viewpoint, Athens was seen as a central topos of power, with a long tradition of playing a protagonistic role in Greek affairs and holding a prominent cultural position that could be traced to the fifth century. The idea of Athens as the cultural capital of the Greek world was, of course, disseminated as early as the fifth century by Athenians and non-Athenians alike in ideological and practical terms. Many non-Athenians also acknowledged its cultural predominance and visited Athens for their education and cultural milieu; pursued diplomatic relations with the Athenians; and demonstrated

6 For example, recent work on the broader role of 'discourse' and the understanding of language as integral part of politics and culture, see Hölscher (2004; 2018). For a recent example of framing art and text in linguistic and semantic terms see Luci (2018); Rous (2019). 
their benevolence by the numerous benefactions (Pagkalos 2018: pp. 81, 96-106). ${ }^{7}$ According to Plutarch, Demetrios Poliorketes wished to capture Athens in the 300s for its strategic importance and its cultural status, for it was 'the beacon-tower of the inhabited world'. ${ }^{8}$ Interestingly, this cultural status quo was directly referenced by Sulla (also passed down to us by Plutarch) as the main reason for sparing the city from destruction; but I will return to this point later. ${ }^{9}$

With the gradual loss of military power due to the changing political landscape of the Hellenistic period, Athens became entangled in an intermittent struggle between autonomy and subjugation. The cultural role of Athens became even more critical and pronounced during the Hellenistic period, informing civic narratives that contextualised, by and large, the political discourse and was cultivated domestically and accordingly disseminated abroad. Even if not all Athenians agreed on the details, a shared self-perception, both as a physical space and an imagined community, was shaped through historical developments and further supported by the polis' institutions. It was the result of long memory processes and, as such, selective in details and malleable. Two key concepts were pronounced during the Hellenistic period: (i) the connection to a glorious past when the Athenians had fought and won many battles to protect the other Greeks, but most importantly their polis; which led to (ii) the polis' democratic polity. ${ }^{10}$ The Athenians increasingly appropriated, via various forms, the historical developments into Athenian civic rhetoric that served the polis, its citizens and external aims.

To return to the chronological framework, the relationship between Rome and Athens began when the Athenians sided with the Romans and Attalos I of Pergamon against the

7 Elements of Athenian rhetoric along the same lines of argument feature in the stance the Athenian embassy observed when they attempted to reconcile with Sulla and avert the destruction of their polis. The envoys narrated the glorious past of Athens, starting with Theseus and Persian Wars, both very central to

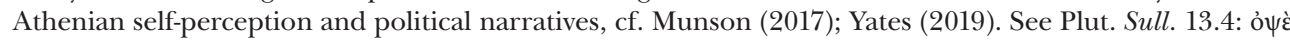

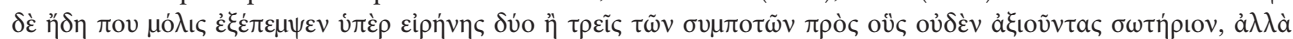

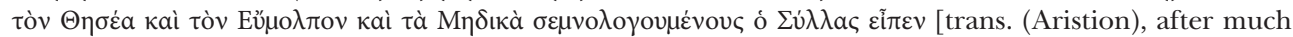
time, at last, sent out two or three of his drinking fellows to ask for peace, to whom Sulla, when they made no demand towards saving the city but talked eloquently about Theseus, and Eumolpos, and the Persian Wars, said...].

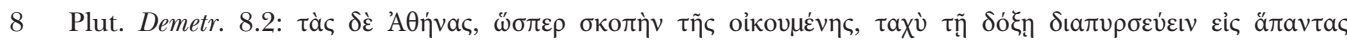

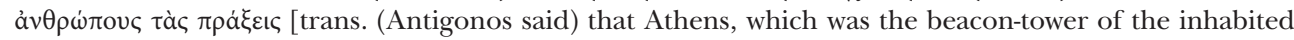
world, would quickly disseminate the glory of their deed to all mankind]; cf. Diod. 20.45.1. See also Kralli (2016: esp. pp. 164-165).

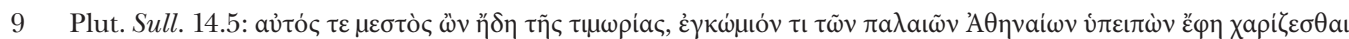

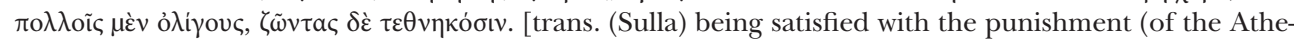
nians), after some praising for the ancient Athenians, he said that he forgave the few in favour of the many, the living in favour of the dead.]. Cf. Kuin (2018) who interprets the sentiments of Plutarch (among other sources) as 'inventions' based on emotional and political intents of the Athenocentrism of the late first and early second century CE Romans. Eckert (2016: pp. 86-102), on the other hand, discusses the events as part of Sulla's attempt to construct his own version of the past events, transmitted differently than the ancient authors.

10 Cf. Hoff \& Rotroff (1997); Canevaro \& Gray (2018); Pagkalos (2018: p. 55; Forthcoming), with ample bibliography. 
Antigonid king Philippos V in the Second Macedonian War (c. 200-196). Livy described the events in his Ab Urbe Condita (31.44.2-9): ${ }^{11}$

[2] tum vero Atheniensium civitas, cui odio in Philippum per metum iam diu moderata erat, id omne in auxilii praesentis spem effudit. [3] nec umquam ibi desunt linguae promptae ad plebem concitandam; quod genus cum in omnibus liberis civitatibus, tum praecipue Athenis, ubi oratio plurimum pollet, favore multitudinis alitur. [4] rogationem extemplo tulerunt plebesque scivit, ut Philippi statuae, imagines omnes nominaque earum, item maiorum eius virile ac muliebre secus omnium tollerentur delerenturque diesque festi, sacra, sacerdotes, quae ipsius maiorumque eius honoris causa instituta essent, omnia profanarentur; [5] loca quoque, in quibus positum aliquid inscriptumve honoris eius causa fuisset, detestabilia esse [...] [8] si quis contra ignominiam prove honore eius dixisset fecissetve, qui occidisset eum, iure caesurum. postremo inclusum, ut omnia, quae adversus Pisistratidas decreta quondam erant, eadem in Philippo servarentur. [9] Athenienses quidem litteris verbisque, quibus solis valent, bellum adversus Philippum gerebant.

[2] Then indeed the people of Athens, in view of the forthcoming help, fully indulged the hatred for Philippos, which had long been keeping restrained due to fear [3] The city does not lack tongues ready to incite the masses; and this phenomenon is encouraged by popular applause, in all free states, but especially in Athens, where oratory is particularly influential. [4] The Athenians immediately formulated a proposal, which the people ratified, that all statues of Philippos, all representations of him, and their inscriptions should be removed and destroy, together with those of all his ancestors, male and female and that all the feast-days, religious rites and priesthoods which had been established in honour the same Philippos or his ancestors should be abolished; [5] even the places in which any memorials or inscriptions in his honour had been set up should be accursed [...] [8] Finally, it was added that all the decrees which had once been passed against the Peisistratidai should be kept in force in the case of Philippos. [9] This was the Athenians' war against Philippos, conducted by means of letters and words, which constitute their sole strength.

The passage invites lengthy analysis, but for the purpose of this paper, I want to focus on three points for the sake of brevity and argument. First, the Athenians exercised their favourite pastime: participation in the Ekklesia and decision-making. Indeed, the Athenians lived in a more or less democratic polity since 229, when they bribed the Macedonian commander away and freed their polis from Antigonid control. ${ }^{12}$ Second, the text records a case of damnatio memoriae, whereupon the Athenians anchored the changes in a radical manner. They erased the names of Macedonian kings from all public records, textual (inscriptions) and visual (inscriptions and removal of statues), altering the very landscape of Athens. They also removed from the list of tribes the two Macedonian-inspired tribes, Antigonis and Demetrias, created more than a century earlier to honour Antigonos Monophthalmos and Demetrios Poliorketes respectively for the liberation of the

11 Translation adapted from Evan T. Sage (LCL 295).

12 Ferguson (1911: pp. 205-206); Habicht (2003: pp. 52-53); Worthington (2021: pp. 132-136). 
polis from Kassandros $(307 / 6) .{ }^{13}$ Finally, we observe the association of the enemy - that is Philippos $\mathrm{V}$, the penultimate ruler of the Macedonian kingdom and the major force opposing the Romans in the First and Second Macedonian Wars - to the Peisistratids. The tyrants of Athens were prominent Others in the constitutional prehistory of the polis and of democracy, the symbol of all things terrible. ${ }^{14}$

The passage highlights the Athenian response in terms of political language and diplomatic skill. Earlier in the same book, Livy (31.15.6-7) lists the honours that the Athenians conferred upon king Attalos I and the Rhodians. In response to the benefactions of Attalos, the Athenians created a new tribe, Attalis. ${ }^{15}$ Thus, at around the same time, the Athenians removed the Macedonian tribes from the top of their tribal list but opted for a new tribe to acknowledge the benefactions of the Pergamene king. In 224/3, the Athenians resorted to the same process for another king, Ptolemaios III Euergetes of Egypt, and created the tribe Ptolemais in his honour. ${ }^{16}$ Thus, in all cases, the Athenians took firm political action - inscribing their benefactors to every aspect of public life, from the political to the religious level. Successive reshuffling of tribe names and political re-organisation constitute the epitome of anchoring practices. ${ }^{17}$ Much more than a reaction based on munificence, framed by the rules of reciprocity, this recurring practice reveals the central issue at stake: the struggle for autonomy and freedom of the Athenians against opposing forces.

\section{Looking at Coins: Sulla, the Stephanephoroi, and Symbolisms}

In the aftermath of Sulla's siege and the partial destruction of the polis, autonomy and freedom were again under threat, and possibly the Athenians had felt this was the case even before the coming of Sulla. There is undoubtedly something substantial behind their choice of siding with Mithridates against the Romans, despite the benefits of their close relationship with the Romans till then. ${ }^{18}$ Apparently, the Athenians believed that the Roman hegemony was collapsing due to the rise of Mithridates and attempted to do away with the Romans' soft control over their polis affairs and regain full autonomy, supported by the king of Pontos. ${ }^{19}$ Aristion, the Athenian magistrate (c. 88), openly

13 Habicht (1997: pp. 196-197); Mikalson (1998: pp. 186-188).

14 Taylor (1991); Azoulay (2017: p. 3 and throughout).

15 Cf. Syll. ${ }^{3}$ 589; Polyb. 16.25-26. Habicht (1990); Worthington (2021: pp. 149-150).

16 Habicht (1992: pp. 74-75); Mikalson (1998: pp. 178-179); Worthington (2021: pp. 139-140).

17 Pagkalos (2018: pp. 92-94).

18 The Athenians were by all probability a civitas foederata et libera (allied and free city) from around the Aitolian War (c. 191-188); see Habicht (1997: pp. 212-213); Worthington (2021: pp. 163-180).

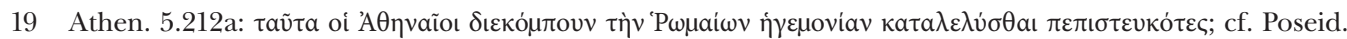
FGrHist 87 F 36. Habicht (1997: pp. 298-300); Kuin (2018: pp. 618-619); Henderson (2020: pp. 278-280); Worthington (2021: pp. 203-205). 
supported Mithridates' plans. Sulla, who was dispatched to deal with Mithridates, soon focused his attempts on Athens to calm the revolutionary ideas of the Greeks. ${ }^{20}$

After the fall of Athens, possibly in 84/3, the Athenians minted a limited series of coins following the New Style (or stephanephoric) civic coinage but with an intriguing addition on the reverse (Figure 1). ${ }^{21}$ There we find the owl standing on an amphora and, on its right, two figures standing next to each other in a fighting stance. The right figure is presented holding a sword on its right hand, moving forward on a thrusting move; the left figure holds a sword on its left hand, while a chlamys is wrapped around its arm. It is hard to miss the figures' identity; these are, of course, the tyrannicides, Harmodios and Aristogeiton - the celebrated symbols of democracy. The figures copy the sculptural pairing of the tyrannicides directly from the statue of Kritios and Nesiotes. ${ }^{22}$ The reverse also bears the inscriptions: $\mathrm{A} \Theta E[\mathrm{NAION}]$ on top and the names of two magistrates, $M E N T \Omega P$ and $M O \Sigma X I \Omega N$, below, all within wreath. Finally, in the obverse of the coin, we find the typical iconography of New-Style Athenian coins, the helmeted head of Athena looking to the right (Figure 1).
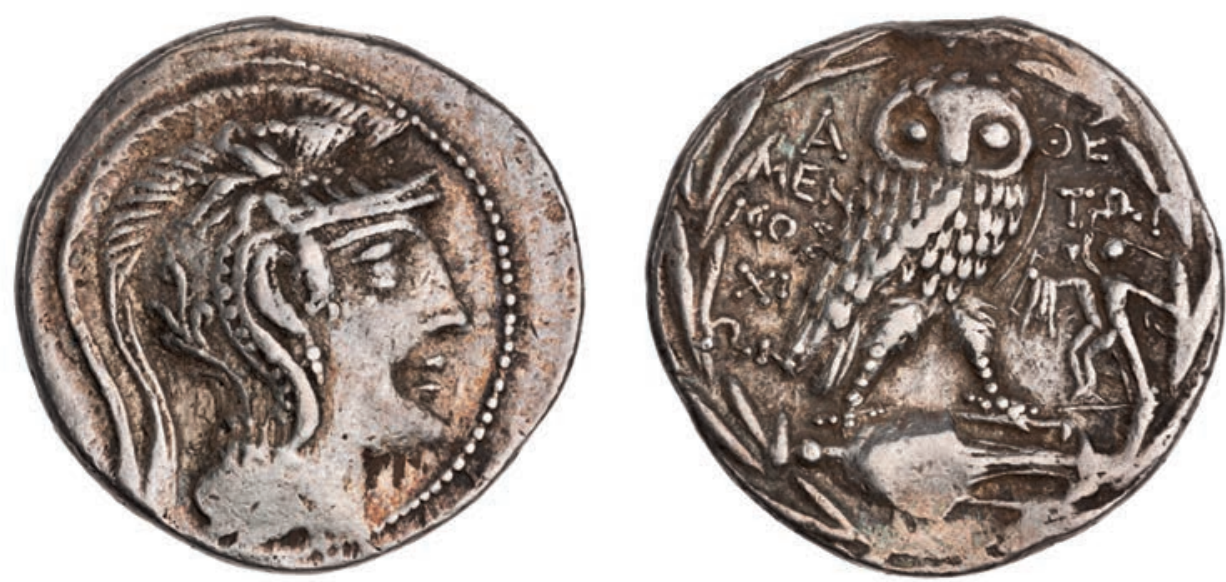

Figure 1: AR Athenian New-Style tetradrachm (17,42g; c. 84/3 BC?). Obv. Helmeted head of Athena to right. Rev. Owl standing on amphora, with Harmodios and Aristogeiton on the

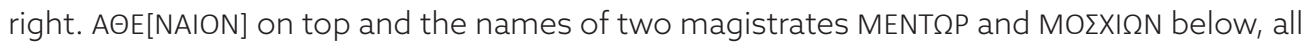
within wreath. Source: ANS 1944.100.24898 (Newell).

20 Santangelo (2007: pp. 35-36).

21 Cf. Thompson (1961: pp. 371-372, Nos 1165-11772; Pl. 130); Habicht (1976: pp. 135-142); Flament (2007: pp. 147-150). Kroll (1993: pp. 81-82) argues for a suspension of Athenian mints for five years and dates this issue at c. 79. However, even with this chronology, the ideological overtones of the iconography, as discussed below, remain the same (if not even more pronounced). The new civic coinage co-existed with Roman coins that entered circulation after the sack of the polis in 86, Papageorgiadou \& Kosmidou (2020: pp. 145-146).

22 Habicht (1976: pp. 135-142); Azoulay (2017: pp. 146-148). 
Scholars have long attempted to explain the iconographical choices on the coins in an attempt to date them. For example, in her seminal, yet now significantly revised, study of the New Style coinage of Athens, Margaret Thompson (1961: pp. 371-372) dated the coins to $118 / 7$, explaining that possibly the iconographic choice relied on a bond between the two mint magistrates, Mentor and Moschion or their 'mutual devotion to the cause of freedom'. ${ }^{23}$ More recently, Vincent Azoulay (2017: pp. 140, 146-148) has interpreted this choice as an instrument of repairing the 'severely strained diplomacy' seeking to create or reaffirm links with the Roman leaders of the time. He further saw the iconographic choice as indicative of the Athenian political culture. He supported the idea of an Athenian agency for the coin's iconography aimed towards internal (Athenian) and external audiences (a gesture to Sulla). ${ }^{24}$ I propose we view it as a case of anchoring changes in a typically Athenian narrative. Indeed, I believe that we can look further for Athenian agency.

The timing of such iconographical choices is telling, and together with the revised dating, they make the choice even more critical of civic ideology. The Athenians had a long tradition of appropriating political (and historical) developments and could not have missed the opportunity to resort to such practices. ${ }^{25}$ At first glance, the iconography may allude to the end of the 'tyrannical' rule of Aristion, as painted by ancient sources, or even of that of Mithridates. ${ }^{26}$ In both cases, it portrays clear links to the Athenian past and imaginary as part of an orchestrated civic response to Sulla, combined with the institution of the Sylleia (IG $\left.\mathrm{II}^{2} 1039\right)$, celebrated only once; ${ }^{27}$ the dedication of statues to the Roman general $\left(I G \mathrm{II}^{2} 4103\right)$; $^{28}$ and his initiation to the Eleusinian Mysteries (Plut. Sull. 26.1). ${ }^{29}$ Notably, this was not the first time the Athenians used their New Style iconography to associate the polis to Roman achievements. For example, in the long continuous series of the stephanephoroi some types carry Apollo Delios (as Delos was a gift of the Romans to Athens), Roma or Roma and Nike establishing a tradition and acting as precursors to the iconography of the coin of Mentor and Moschion. ${ }^{30}$

23 On the debates and dating of the New Style coinage of Athens see Lewis (1962); Mørkholm (1984); Mattingly (1990); Kroll (1993; 1997); Oliver (2001); Apostolou (2010); de Callataÿ (2011).

24 Price (1987: p. 95). Contra de Callatä (2011: pp. 77-78) who sees Roman presence in the mint. However, de Callataÿ also argues for economic reasons ('pragmatic monetary affairs') that led the Athenians and the Romans in using the stephanephoroi. However, in his approach, he removes most of the agency from the Athenians and offers it mostly to their rulers (the Romans), a case that may contradict the importance of coinage for civic identity as a manifestation of autonomy and ideology.

25 Kuin (2016: p. 165); Azoulay (2017: p. 148).

26 Cf. Plut. Mor. 809E, where Aristion is described along with Nabis and Catiline as enemies of the state and

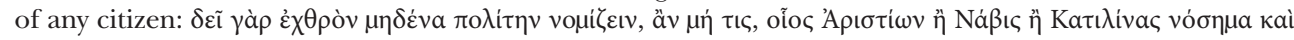

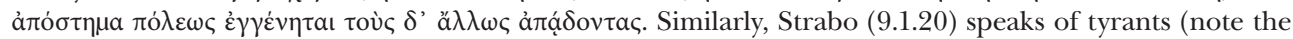
plural) that Mithridates VI put in charge of Athens.

27 According to Raubitschek (1951), the games in honour of Sulla were a renaming of the ancient Theseia. Hoff (1997: p. 43); Kleinschmidt (2011); Parigi (2013: p. 448).

28 For a second example, see Geagan (2011: p. 223).

29 Kuin (2017: p. 165); Worthington (2021: p. 213). For the connection between these elements see also Kleinschmidt (2011).

30 Thompson (1961: pp. 226, 359, and 362 respectively). 
Arguably, Sulla himself was aware of the potential and possibilities that such images could create to establish a particular political narrative and disseminate it to the public (Athenian, Roman, or other). According to Appian (B Civ. 1.7.57), as Sulla was marching his legions against the city of Rome, he made direct references to Marius and Sulpicius as 'tyrants'. At the same time, he was promoting himself as the 'liberator' of Rome. ${ }^{31}$ It might be that Sulla placed copies of the statues of the Athenian tyrannicides in the Capitol for the same reasons of promoting the narrative of the "liberator' ${ }^{32}$ The fire that partly destroyed the Capitol in 83 provided an excellent opportunity for self-promotion, and it seems highly plausible that the preceding rhetoric of the 'liberator' and 'tyrannicide' linked with Sulla in Athens inspired Sulla to appropriate and use them in Rome. ${ }^{33}$

Other evidence suggest a collective, civic Athenian agency rather than an initiative by the two magistrates or, even, Sulla. In his campaign against Mithridates, Sulla had a mobile mint in operation to cover war expenses. Several Roman issues were minted during the campaign with a Roman-centric iconography that is closely connected to Sulla. ${ }^{34}$ In the same period, the years $84 / 3$, the Sullan mint produced a series of aurei and denarii with the head of Venus wearing a diadem. A standing Cupid holding a palm branch facing Venus is on its right, and the inscription L(UCIUS) SULLA complete the obverse. On the reverse, the iconography includes two trophies with a jug and a lituus between them, with the inscription IMPER(ATOR) above and ITERU(M) below (Figure 2)..$^{35}$

Sulla cultivated specific links to Aphrodite, similar to those that Pompey would promote some years later. According to Appian (B Civ. 1.97), the Senate addressed Sulla as Epaphroditus, he received an oracle that connected him to the goddess, and then dedicated a golden crown and an inscribed double-axe to the Temple of Aphrodite at Aphrodisias. ${ }^{36}$ Moreover, after his victory at Chaironeia and Orchomenos in Boiotia, Sulla raised two trophies dedicated to 'Mars, Victory, and Venus' (Plut. Sull. 19.5). The iconographical choice for the reverse of these coins is telling; Sulla disseminated the message of the success of the Roman arms against the aggressors.

However, the case is that coins of a similar iconography to the stephanophoric coinage of Mentor and Moschion appears in the so-called Pseudo-Athenian coins, which emulate the Athenian stephanephoroi (Figure 3). The obverse follows exactly the Athenian stephanephoroi iconography. Yet, the reverse depicts an owl standing on amphora with A on it, with MAPKOY monogram to the left and TAMIOY to the right, all within wreath. The monograms designate the man responsible for the expenses of the Roman campaign, Marcus [Terentius Varro] Lucullus, brother of Lucius Licinius Lucullus,

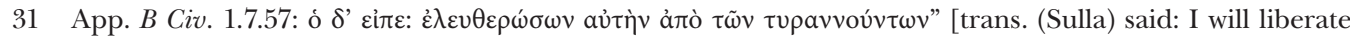
her (Rome) from its tyrants]. On the rhetoric of libertas see Tatum (2020).

32 On the eastern slope of the hill, Sulla had set up a statuary group as part of his triumphs in the East, one that could accommodate an image of the tyrannicides. Only the statue of Aristogeiton has survived and was unearthed in excavations of 1937; Azoulay (2017: pp. 141-146).

33 For full discussion, Azoulay (2017: pp. 139-161).

34 Cf. RRC 359, 366-368, 375.

$35 R R C 359 / 1$ and 359/2; Sear 276.

36 For the cult of Aphrodite at Aphrodisias see Brody (2001). 

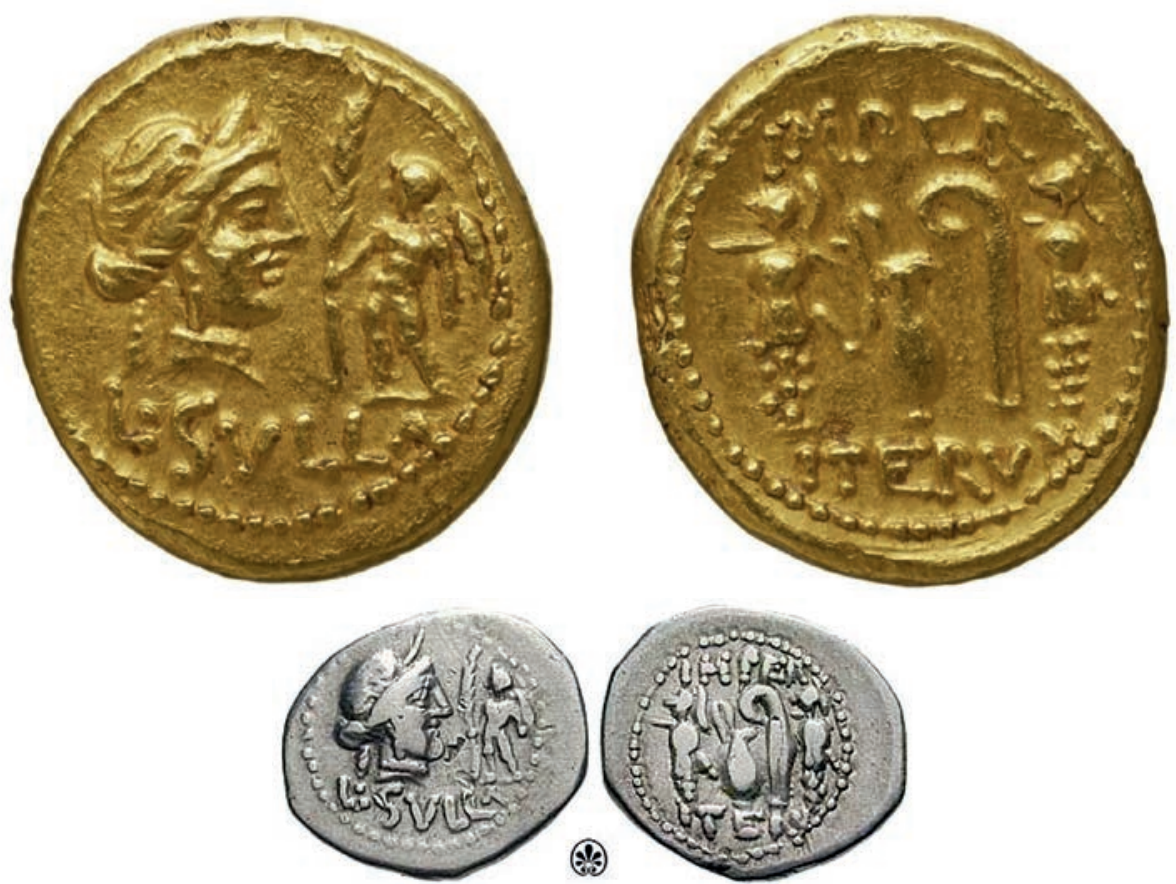

Figure 2: Aureus (10.81g; above) and AR denarius (below) of L. Cornelius Sulla (moving mint; 84/3). Obv. Head of Venus looking right, with eros standing in front of it looking left with palm-tree branch. Inscription L(UCIUS) SULLA below, all within a border of dots. Rev. Two trophies left and right, with lituus and jug between them. Inscription IMPER(ATOR) above and ITERU(M) below, all within a border of dots. Sources: Bibliothèque nationale de France, département Monnaies, médailles et antiques, REP-21375; CNG.

Roman Senator and close companion of Sulla. ${ }^{37}$ Another pseudo-Athenian stephanephoros coin bears an owl standing on an amphora, framed by two trophies left and right the trophies of Sulla's victories at Chaironeia and Orchomenos - all within wreath. ${ }^{38}$ One must note, in this case, the absence of the ethnic of the issuing authority.

The absence of genitive plural of the collective Athenian issuing authority that could confirm an Athenian agency for these coins is telling, in contrast to the stephanophoric issue of Mentor and Moschion. These are the coins that Sulla minted to fund his campaign using the sacred treasures of Epidauros, Olympia, and Delphoi. ${ }^{39}$ Naturally, the well-established style and status of the Athenian tetradrachms are the reasons behind these issues, but clearly, this is a case of a different agency with the Roman magistrate replacing the Athenians.

37 Cf. the dedications by the Athenian people and the Areopagos $I G \mathrm{II}^{2} 4104,4105$.

38 Camp et al. (1992).

39 Plut. Sull. 3-4; Diod. 38-39.5; Paus. 9.7.5-6. Ruggeri (2006). 

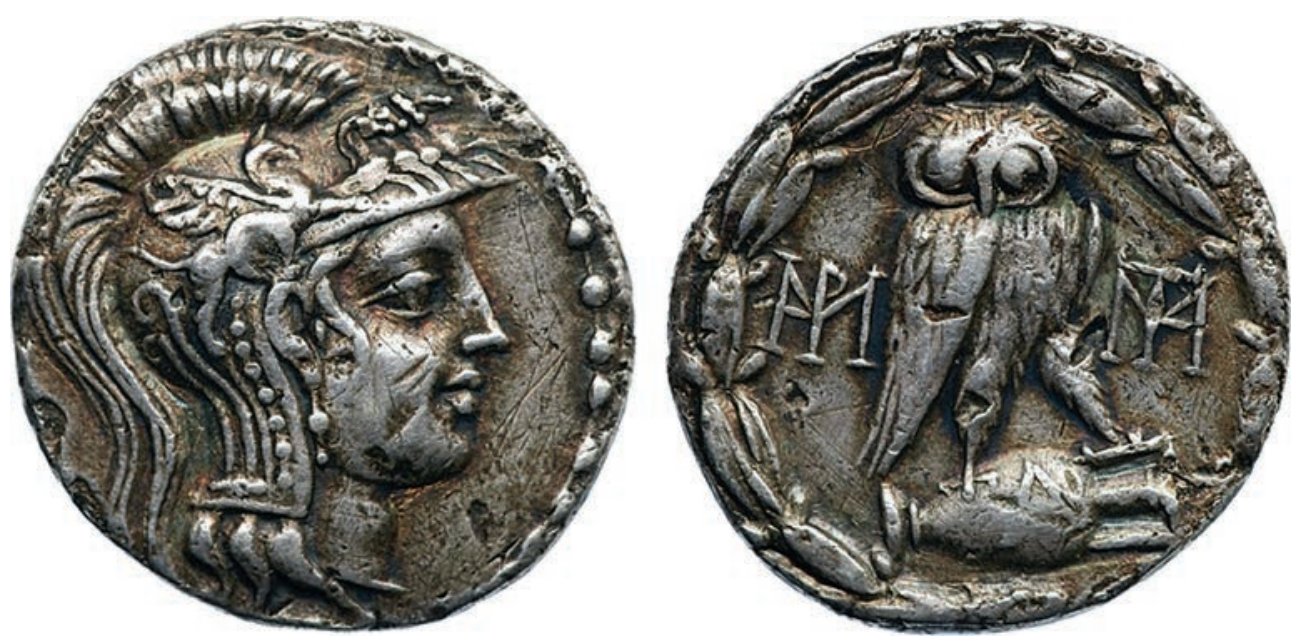

Figure 3: AR Pseudo-Athenian tetradrachm minted under L. Cornelius Sulla (moving mint; 84/3). Obv. Helmeted head of Athena to the right within border of dots. Rev. Owl standing on amphora with an inscribed A on it, with MAPKOY monogram to the left and TAMIOY to the right, all within wreath. Source: Thompson 1293 \& 1313

Given the different uses, timeframe, and audiences, I think it is more plausible to assume that the agency behind the iconographical choice for the stephanophoric issue with the Harmodios and Aristogeiton rests on Athenian agents. The Athenians were capable of following an exceedingly long tradition of political appropriation of historical events, another profound instance of anchoring if I may: they associated the sack of Athens with the expulsion of the tyrant(s) Aristion and/or Mithridates. However, in contrast to previous uses of the tyrannicides back in 307 (Diod. 20.46.2) (n) $^{40}$ the is no explicit return to democracy. Thus, one ought to enquire further on the reasons.

The events of $307 / 6$, the liberation of Athens by the Antigonids, is, I believe, the closest comparable example to the sack of Athens by Sulla. For it was too a period of political instability, when the Athenians were under the control of the forces of Kassandros and his epimeletes, with their autonomy and freedom under question. In Diodoros' account (20.46), the Antigonid Saviours were integrated into the political and religious practices and calendar of the Athenians with the erection of the altar to the Soteres (Saviours) and annual games and sacrifices in their name. ${ }^{41}$ Similarly, Demetrios was offered the Parthenon as a residence and, after an extraordinary re-arrangement of the religious calendar, was initiated to the Eleusinian Mysteries. Politics and religion seem to be tightly knit together when the latter can serve civic objectives. Therefore, we should approach the divine honours bestowed upon Antigonos and Demetrios as intending to serve the public good. Indeed, the level of integration of the Saviours into Athenian traditions was

40 Mikalson (1998: p. 79).

41 Cf. Plut. Demetr. 10.2. 
multi-level and thus unusual. This may be another indication that the Athenians -the elite- understood the need to navigate through precarious times with as much conformity as possible (Pagkalos 2018: pp. 89-90). To return to the first century, it seems that at the time of Sulla, Athenian political and religious affairs were no less intertwined than in earlier periods, and offered, once again, the opportunity to cater for the needs of the polis' survival.

\section{Turning to the Stone: Some Epigraphic Evidence on Political Anchoring}

As we have seen earlier, something similar was attempted for Sulla, although not at all so majestic. First, references preserved in the epigraphic record attest to the Sylleia, games held in honour of Sulla, in all probability inaugurated during the second visit of the consul at Athens in 84/3. An inscribed base that bears a cutting in the top for a torch belongs to an ephebic dedication to Hermes for a victory at the lampas (torch) race (IG $\left.\mathrm{II}^{3} 4,375\right):{ }^{42}$

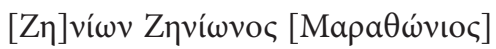

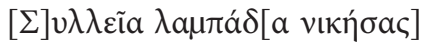

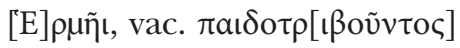

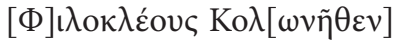

5

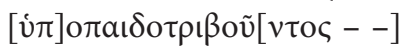

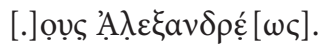

1

[Ze]nion, the son of Zenion [of Marathon]

[having been victorious] in the torch race at the [S]ylleia

(dedicated this) to Hermes when paidotribes (trainer) was

[F]ilokles [from] Kolonai

5

and when [hyp]opaidotribes (deputy trainer) was ...

... of Alexandria.

However, the games were short-lived and, in all probability, did not outlive Sulla. According to Antony Raubitschek (1951: pp. 49-57), the games were not a new addition but a refashioning of the Theseia, a festival established in the fifth century. ${ }^{43}$ During the same visit, Sulla was initiated in the Eleusinian Mysteries (Plut. Sull. 26) ${ }^{44}$ and honoured with

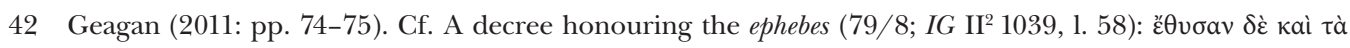
$\Sigma v \lambda \lambda \varepsilon \tilde{\imath}[\alpha]$.

43 Cf. Kleinschmidt (2011); Henderson (2020: pp. 287-288).

44 Kuin (2017: p. 159). The initiation to the mysteries seems to belong to the range of honours the Athenians offer to their 'benefactors', where clearly this is a political tool that elevated the foreigner and made Athenian narratives prevalent through the framing of any external candidate to a very Athenian ritual. Later, Pompey was initiated (62 BCE) cf. Kroll (1993: pp. 99-100); Hoff (2005: p. 332) and possibly Marcus Antonius (Plut. Ant. 23.2). 


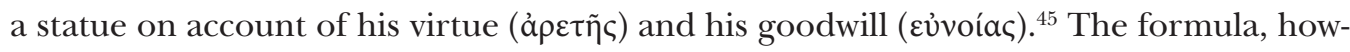
ever, is typical in dedications. Between the honorific statue and the short-lived festival, it seems that the Athenians were reluctant to bestow extraordinary honours upon someone who nearly destroyed their polis. ${ }^{46}$ Interestingly, around the same time, a Hellenistic statue at the Amphiareion of Oropos was rededicated to Sulla, part of a trend of similar acts for other Roman officials. ${ }^{47}$ It may be that these honours were conferred upon Sulla due to the restoration of Athenian control over the islands of Imbros, Lemnos, Skyros, and Delos. ${ }^{48}$ However, compared to the statues and honours for the Antigonids back at the end of the fourth century, we see evident discrepancies in the Athenians' response.

The reason should be sought to the actual predicament of the Athenians - the polis laid in ruins, many of its buildings destroyed, and many of its citizens slaughtered by the Roman legions. ${ }^{49}$ Furthermore, if indeed the rule of Aristion was the rule of a tyrant, thus raising questions about democracy and the role of Mithridates, then with Sulla, we do not see any political change for the better. Even though scholars agree that Sulla did not impose a 'new' constitution, certain restrictions are visible. For example, the absence

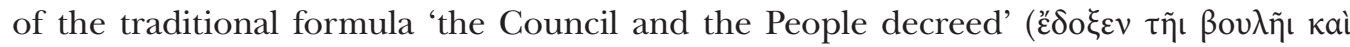
$\tau \tilde{\omega} \iota \delta \dot{\mu} \mu \omega \iota)$ from Athenian decrees for more than thirty years demonstrates a firm turn towards a more restrictive, less democratic regime..$^{50}$

As the epigraphic evidence attests, it was probably in 49/8, after Caesar's victory over Pompey, that the Athenians shed some of the restrictions. Caesar demonstrated leniency towards the Athenians, although they had sided with Pompey. Caesar's famous retort: 'how often [...] the glory of the Athenian ancestors will save Athens' (Appian, B Civ 2.88) echoes a similar discussion between the Athenian ambassadors and the Romans that took place before the destruction of the polis by Sulla. ${ }^{51}$ For his stance and earlier benefactions towards the city, Caesar was honoured as Soter and Euergetes with two statues in the Athenian Agora. ${ }^{52}$

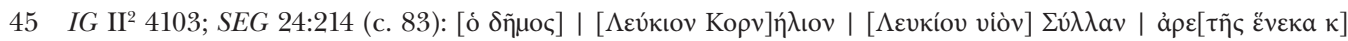

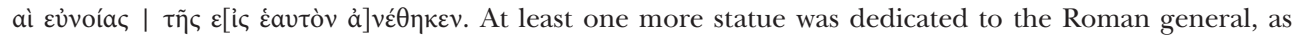
another inscribed statue base from the Athenian Agora demonstrates, see Geagan (2011: p. 223).

46 Also, Hoff (1997: p. 43). See also Eckert (2016: pp. 94-95), who discusses the Athenian response in connection to the Pythian oracle they received (Paus. 1.20.7) that would have brought forth the memory of the oracle Theseus received about the polis (Plut. Thes. 24.5).

47 Petrakos (1968: pp. 154-170); Palagia (1997: p. 82). Cf. I.Oropos 308 (= IG VII 413; Syll. ${ }^{3} 747$ ).

48 Hoff (1997: p. 43); Worthington (2021: pp. 212-213).

49 Hoff (1997: pp. 40-41); Ruggeri (2006); Mango (2010: pp. 117-125); Kuin (2018); Parigi (2019); Worthington (2021: 210-213).

50 App. Mithr. 6.38-39) reports that Sulla forgave (the Athenians) and imposed laws that were very close to those that have been previously determined for them by the Romans. See Geagan (1964); Kuin (2017); Antela-Bernárdez (2019); Worthington (2021: pp. 213-215). The first surviving decree with the formula is dated in 49/8 ( $I G \mathrm{II}^{2} 1047$; cf. $\left.I G \mathrm{II}^{2} 1046\right)$.

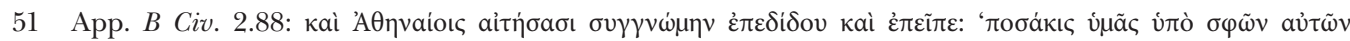

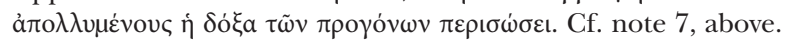

52 SEG 14:121; Geagan (2011, H249-251); Heijnen (2018: p. 86); Worthington (2021: pp. 228-229). 
To return to the iconography of Mentor and Moschion's issue, Sulla and his actions against the polis (from actual or looming destruction to changes in the polity) make the appearance of the tyrannicides discussed previously even more intriguing. The Athenians may have chosen this iconographical theme despite, or better, due to all their hardships. Throughout the Hellenistic period, the Athenians had experienced similar changes of fate, although they may never have come so close to actual destruction. However, they would always return to a 'democracy', thus anchoring all changes in a very central, Athenian narrative. It may be that a pro-Roman party could have promoted Sulla as a tyrant-slayer, embedding the events around the siege of the polis in the narrative of liberation. ${ }^{53}$ Nevertheless, it may also be that this anchoring was a subtle, yet clear to the internal audience, comment against Sulla and the Romans. Of course, Sulla was not a boor. He could have understood the comment against the conquering Roman forces and himself. However, as seen in the evidence of his campaign in Southern Greece, he was certainly aware of the financial and political capital of coinage, as he operated a moving mint and circulated denarii and copies of local coinage (as in the case of the pseudo-Athenian stephanephoroi). ${ }^{54}$ Then, it may be that he allowed the coins to circulate despite their ambiguous message. At the very least, he used the message for his own agenda back in Rome, while the Athenians could once again wage war in litteris verbisque, echoing Livy's perspective.

\section{Conclusion}

In this article, I discussed some mechanisms of anchoring innovations, that is the process of reformulating developments and situating them within a familiar language. What I hope is apparent here is that the Athenians possessed an established tradition they could use depending on circumstances. From the tradition and their status as a centre of culture, the Athenians would not resort to extravagant honours since the ambient situation could not change, and their (relative) autonomy or freedom was not actively at stake. This negotiation mode of power and internal control of the narrative may not have always been clear to the outsiders. However, the Athenians reimplemented many aspects every time a possibility for tangible benefits or the opportunity to become something more than a subjugated polis presented themselves. They repeated part of these honours and anchoring practices with all key Roman figures of the last period of the Republic: Pompey, Caesar, Brutus, Marcus Antonius, and, of course, Augustus. ${ }^{55}$ This practice allowed for the creation of a common space for negotiation, part of the Athenian response instrumentalised throughout the Hellenistic period. The recipe was remarkably successful for the polis even if the period of Sulla was a dark moment; after all, it was the only precarious circumstance. Typically, the Athenians survived every decision

53 Kuin (2017: p. 165).

54 Zoumbaki (2018: pp. 362-3367); Papageorgiadou \& Kosmidou (2020: p. 160).

55 Heijnen (2018). 
to side with the wrong side unscathed, situating events into a familiar political discourse while inviting external favours or leniency. ${ }^{56}$ In response, every time the Athenians were treated with respect, they would answer in kind, further appropriating changes in their political discourse while bestowing honours to foreigners and employing political symbolism.

The question that remains is if this was their only choice. The short answer is no, it was not, as the epigraphic evidence attests. There, the political language, the core element of political culture, offers a much more nuanced image, but this is a topic for another, more extended paper.

\section{Bibliography}

Antela-Bernárdez, B. (2019). The Last Tyrants of Athens. Karanos, 2, 43-53.

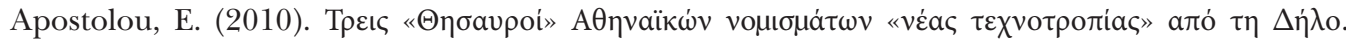

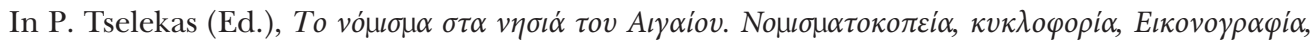

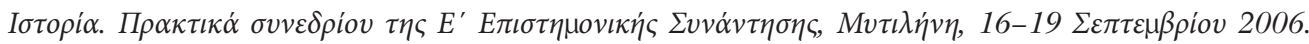

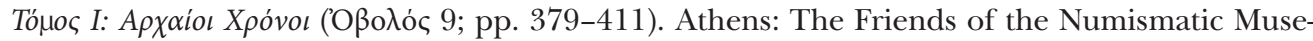
um.

Azoulay, V. (2017). The Tyrant-Slayers of Ancient Athens: A Tale of Two Statues. Oxford: Oxford University Press.

Brody, L. R. (2001). The Cult of Aphrodite at Aphrodisia in Caria. Kernos, 14, 93-109.

Camp, J. M., Ierardi, M., McInerney, J., Morgan, K. C., \& Umholtz, G. (1992). A Trophy from the Battle of Chaironeia of 86 B. C. American Journal of Archaeology, 96(3), 443-455.

Canevaro, M., \& Gray, B. (Eds.). (2018). The Hellenistic Reception of Classical Athenian Democracy and Political Thought. Oxford: Oxford University Press.

Crawford, M. H. (1974). Roman Republican Coinage. Cambridge: Cambridge University Press.

de Callataÿ, F. (2011). More than It Would Seem: The Use of Coinage by the Romans in Late Hellenistic Asia Minor (133-63 BC). American Journal of Numismatics, 23, 55-86.

Conwell, D. H. (2008). Connecting a City to the Sea: The History of the Athenian Long Walls. Leiden: Brill.

Eckert, A. (2016). Lucius Cornelius Sulla in der antiken Erinnerung. Jener Mörder, der sich Felix nannte (Millennium-Studien, 60). Berlin: De Gruyter.

Ferguson, W. S. (1911). Hellenistic Athens: An Historical Essay. London: MacMillan.

Flament, C. (2007). Le monnayage en argent d'Athènes: De l'époque archaïque à l'époque hellénistique (c. 550- c. 40 av. J.- C.) (Etudes numismatiques, 1). Louvain-la-Neuve: Association de numismatique professeur Marcel Hoc.

Geagan, D. L. (1964). The Athenian Constitution After Sulla (Hesperia Supplements, 12). Princeton, NJ: American School of Classical Studies at Athens.

Geagan, D. L. (2011). Inscriptions: The Dedicatory Monuments (The Athenian Agora, 18). Princeton, NJ: The American School of Classical Studies at Athens.

56 For a similar reading, see also Mango (2010: p. 124); Eckert (2016: p. 95). 
Habicht, C. (1976). Zur Geschichte Athens in der Zeit Mithridates' VI. Chiron, 6, 127-142.

Habicht, C. (1990). Athens and the Attalids in the Second Century B.C. Hesperia, 59, 561-577.

Habicht, C. (1992). Athens and the Ptolemies. Classical Antiquities, 11, 68-90.

Habicht, C. (1997). Athens from Alexander to Antony. Cambridge, MA: Harvard University Press.

Habicht, C. (2003). Athens after the Chremonidean War: Some Second Thoughts. In O. Palagia, \& S. V. Tracy (Eds.), The Macedonians in Athens, 322-229 B.C. Proceedings of an International Conference Held at the University of Athens, May 24-26, 2001 (pp. 52-55). Exeter: Oxbow.

Heijnen, S. (2018). Athens and the Anchoring of Roman Rule in the First Century BCE (67-17). Journal of Ancient History, 6(1), 80-110.

Henderson, T. R. (2020). The Springtime of the People: The Athenian Ephebeia and Citizen Training from Lykourgos to Augustus. Leiden: Brill.

Hoff, M. C. (1997a). Laceratae Athenae: Sulla's Siege of Athens in 87/6 B.C. and Its Aftermath. In M. C. Hoff, \& S. I. Rotroff (Eds.), The Romanization of Athens: Proceedings of an International Conference Held at Lincoln, Nebraska (April 1996) (pp. 33-51). Oxford: Oxbow.

Hoff, M. C. (2005). Athens Honors Pompey the Great. In L. de Blois, J., Bons, T. Kessels, \& D. M. Schenkeveld (Eds.), The Statesman in Plutarch's Works, II: The Statesman in Plutarch's Greek and Roman Lives; Proceedings of the Sixth International Conference of the International Plutarch Society, Nijmegen/Castle Herner, May 1-5, 2002 (pp. 327-336). Leiden: Brill.

Hoff, M. C., \& Rotroff, S. I. (Eds.). (1997). The Romanization of Athens: Proceedings of an International Conference Held at Lincoln, Nebraska (April 1996). Oxford: Oxbow.

Hölscher, T. (2004). The Language of Images in Roman Art. Cambridge: Cambridge University Press. Hölscher, T. (2018). Visual Power in Ancient Greece and Rome: Between Art and Social Reality. Oakland, CA: University of California Press.

Kleinschmidt, T. (2011). Die Sylleia und die attischen Tetradrachmen der Münzmeister Eumelos und Theoxenides. In O. Pilz, \& M. Vonderstein (Eds.), Keraunia: Beiträge zu Mythos, Kult und Heiligtum in der Antike (pp. 131-160). Berlin: De Gruyter.

Kralli, I. (2016). Attitudes to Hellenistic Athens: To Sneer or Revere? In A. Powell, \& K. Meidani (Eds.), The Eye-Sore of Aigina: Anti-Athenian Attitudes in Greek, Hellenistic and Roman History (pp. 163-185). Swansea: Classical Press of Wales.

Kroll, J. H. (1993). The Greek Coins (The Athenian Agora, 26). Princeton, NJ: The Americal School of Classical Studies in Athens.

Kroll, J. H. (1997). Coinage as an Index of Romanization. In M. C. Hoff, \& S. I. Rotroff (Eds.), The Romanization of Athens: Proceedings of an International Conference Held at Lincoln, Nebraska (April 1996) (pp. 135-150). Oxford: Oxbow.

Kuin, I. N. I. (2017). Anchoring Political Change in Post-Sullan Athens. In T. M. Dijkstra, I. N. I. Kuin, M. Moser, \& D. Weidgenannt (Eds.), Strategies of Remembering in Greece Under Rome (100 $B C-100$ AD) (pp. 157-168). Leiden: Sidestone Press.

Kuin, I. N. I. (2018). Sulla and the Invention of Roman Athens. Mnemosyne, 71(4), 616-639.

Lewis, D. M. (1962). The Chronology of the New Style Coinage of Athens. The Numismatic Chronical and Journal of the Royal Numismatic Society, 2, 275-300.

Luci, F. (2018). Monuments and Inscriptions in Republican Rome: Linguistic Framework for Interpreting Art and Text. Diss., Durham University.

Mango, E. (2010). Tanta vis admonitionis inest in locis. Zur Veränderung von Erinnerungsräumen 
im Athen des 1. Jahrhunderts v. Chr. In R. Krumeich, \& C. Witschel (Eds.), Die Akropolis von Athen im Hellenismus und in der römischen Kaiserzeit (pp. 117-155). Wiesbaden: Reichert Verlag.

Mattingly, H. B. (1990). The Beginning of Athenian New Style Silver Coinage. The Numismatic Chronicle, 150, 67-78.

Mørkholm, O. (1984). The Chronology of the New Style Coinage of Athens. Museum Notes, 29, 29-42.

Munson, R. V. (2017). Thucydides and Myth: A Complex Relation to Past and Present. In S. L. Forsdyke, E. Foster, \& R. K. Balot (Eds.), The Oxford Handbook of Thucydides (pp. 257-266). Oxford: Oxford University Press.

Oliver, G. J. (2001). The Politics of Coinage: Athens and Antigonus Gonatas. In A. Meadows, \& K. Shipton (Eds.), Money and Its Uses in the Ancient Greek World (pp. 32-52). Oxford: Oxford University Press.

Pagkalos, M. E. (2018). Perceiving the Past in the Early Hellenistic Period: The Uses of the Past in Remodelling Reality. Diss., University of Leicester.

Pagkalos, M. E. (Forthcoming). Politics, Memory and Representation in Early Hellenistic Athens: Approaching the Athenian Political Imaginary.

Palagia, O. (1997). Classical Encounters: Attic Sculpture After Sulla. In M. C. Hoff, \& S. I. Rotroff (Eds.), The Romanization of Athens: Proceedings of an International Conference Held at Lincoln, Nebraska (April 1996) (pp. 81-95). Oxford: Oxbow.

Papageorgiadou, C., \& Kosmidou, E. (2020). Denarii Hoards and Coin Circulation in Greece During the $2^{\text {nd }}$ and $1^{\text {st }}$ Centuries BC. In P. Marchetti, \& C. Papageorgiadou (Eds.), Réflexions sur la circulation des monnaies romaines républicaines en Grèce et dans les Balkans/Reflections on the Circulation of Roman Republican Coinage in Greece and the Balkans (pp. 133-210). Athens: Institute of Historical Research, National Hellenic Research Foundation.

Parigi, C. (2013). The Romanization of Athens: Greek Identity and Connectivity between Athens and Rome in the 1st Century BC. In L. Bombardieri, A. D' Agostino, G. Cuarducci, V. Orsi, \& S. Valentini (Eds.), SOMA 2012. Identity and Connectivity: Proceedings of the 16th Symposium on Mediterranean Archaeology, Florence, Italy, 1-3 March 2012 (BAR International Series, 2581; Vol. 1; pp. 447-455). Oxford: Archaeopress.

Parigi, C. (2019). Atene e il sacco di Silla. Evidenze archeologiche e topografiche fra l'86 e il 27 a.C. (Kölner Schriften zur Archäologie, 2). Wiesbaden: Reichert Verlag.

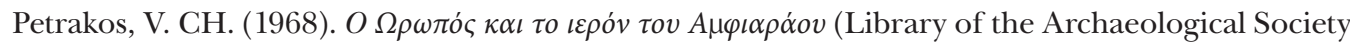
of Athens, 63). Athens: Archaeological Society of Athens.

Price, M. J. (1987). Southern Greece. In A. M. Burnett, \& M. H. Crawford (Eds.), The Coinage of the Roman World in the Late Republic: Proceedings of a Colloquium Held at the British Museum in September 1985 (BAR, 326; pp. 95-103). Oxford: Oxford University Press.

Raubitschek, A. E. (1951). Sylleia. In P. R. Coleman-Norton (Eds.), Studies in Roman Economic and Social History in Honor of Allan Chester Johnson (pp. 49-75). Princeton, NJ: Princeton University Press.

Rous, S. A. (2019). Reset in Stone: Memory and Reuse in Ancient Athens. Madison, WI: The University of Wisconsin Press.

Ruggeri, C. (2006). Silla e la conquista di Atene nell' 86 a.C. In P. Amann, M. Pedrazzi, \& H. Taeuber (Eds.), Italo - Tusco - Romana: Festschrift für Luciana Aigner-Foresti zum 70. Geburtstag am 30. Juli 2006 (pp. 3154-3324). Vienna: Holzhausen Verlag. 
Santangelo, F. (2007). Sulla, the Elites and the Empire: A Study of Roman Policies in Italy and the Greek East (Impact of Empire, 8). Leiden: Brill.

Sear, D. R. (1988). Roman Coins and Their Values. London: Spink Books.

Sluiter, I (2017). Anchoring Innovation: A Classical Research Agenda. European Review, 25(1), 20-38.

Taylor, M. W. (1991). The Tyrant Slayers: The Heroic Image in Fifth Century B.C. Athenian Art and Politics. Salem, NH: Ayer.

Tatum, J. (2020). A Great and Arduous Struggle: Marcus Antonius and the Rhetoric of Libertas in 44-43 BC. In C. Balmaceda (Ed.), Libertas and Res Publica in the Roman Republic (Impact of Empire, 37; pp. 189-215). Leiden: Brill.

Thompson, M. E. (1961). New Style Silver Coinage of Athens (Numismatic Studies, 10). New York: American Numismatic Society.

Worthington, I. (2021). Athens After Empire: A History from Alexander the Great to the Emperor Hadrian. Oxford: Oxford University Press.

Yates D. C. (2019). States of Memory: The Polis, Panhellenism and the Persian War. Oxford: Oxford University Press.

Zoumbaki, S. B. (2018). Sulla, the Army, the Officers, and the Poleis of Greece: A Reassessment of Warlordism in the First Phase of the Mithridatic Wars. In T. N. del Hoyo, \& F. L. Sanchez (Eds.), War, Warlords and Interstate Relations in the Ancient Mediterranean (pp. 351-379). Leiden: Brill.

Dr. Manolis E. Pagkalos / m.pagkalos@rug.nl

Department of Ancient History

University of Groningen

Oude Kijk in 't Jatstraat 26, 9712 EK, Groningen, the Netherlands 